\title{
Participation, Dialogue and Civic Engagement: Understanding the Role of Organized Civil Society in Promoting Active Citizenship in the European Union
}

\author{
Dr. Cristiano Bee \\ School of Politics \\ University of Surrey \\ GU2 7XH Guildford \\ UK \\ c.bee@surrey.ac.uk \\ Dr. Roberta Guerrina \\ School of Politics \\ University of Surrey \\ GU2 7XH Guildford \\ UK \\ r.guerrina@surrey.ac.uk
}

CRISTIANO BEE \& ROBERTA GUERRINA

University of Surrey, School of Politics UK|

\begin{abstract}
This article looks at current policies concerning the civic and political participation of youths, women, migrants and minorities in the European Union. It highlights the ways in which active citizenship and civic engagement have become a political priority for European institutions. Representation of local policy actors at the supranational level and strategies for the inclusion of civil society provide a platform for evaluating the impact of Europeanization at the national and subnational level. The article focuses on key discourses and narratives associated with specific policy frames (e.g. European citizenship, European social policies, and the European public sphere). Some of the key questions addressed by the article are: What are the strategies that are employed, both by the European institutions in Brussels and organized civil society, to enhance participation and reciprocal communication? What vision of governance do practices such as active engagement and civil dialogue represent? Drawing on current theories of governance, our article contributes to the debate about the European public sphere (EPS) by evaluating the role of organized civil society (OCS) in bridging the gap between European institutions and national polities. Equally, our focus on traditionally marginal groups provides a platform for assessing the institutionalization of the 'European social dimension'.
\end{abstract}

KEY WORDS: Active citizenship, political participation, public sphere, civil dialogue, civil society

\section{Introduction}

This article draws on the work of a project looking at Processes Influencing Democratic Ownership and Participation (PIDOP) in Europe, sponsored by the European Commission's $7^{\text {th }}$ Framework Programme. In particular, it presents some of the findings from policy analysis that looked at the civic and political participation of youths, women, migrants and minorities in Europe. The article reflects upon the most recent attempts of the European Union (EU) to reinvigorate the basis of participatory democracy at every level of European governance. Our central argument is that active 
citizenship has become an increasingly central area of policy for European institutions as a vehicle for facilitating the development of a European public sphere (EPS). Our main aim here is to outline the drivers of this process and unpack the factors that - at the level of the EU - have determined this shift in political discourse. The article draws on policy analysis to explain the emergence of this new political discourse at the European level between 2005 and 2010.

The democratic crisis triggered by the rejection of the European Constitutional Treaty in 2005 provided an opportunity to make active citizenship a concrete policy area/objective (Kingdon, 2011). Despite the criticisms of the European Commission's efforts to reinvigorate the democratic basis of the EU, WallströmWallstrom's 2005 initiative is worthy of notice ${ }^{1}$. Her approach is based on a wide set of programmes (e.g. Plan D for Democracy, Dialogue and Debate) aimed at promoting a citizens'orientated form of European integration (Commission of the European Community CEC, 2005). This strategy is prevalent in institutional discourse and was recently introduced in the Treaty on the Functioning of the EU Treaties under Article 11 of Lisbon. It seeks to establish a wider basis for the participation and engagement of stakeholders' networks, nongovernmental organizations (NGOs) and the activists that form the core of European civil society. Issues such as active citizenship, representation of local policy actors at the supranational level, strategies for civic engagement and empowerment of civil society organizations become benchmarks for evaluating the impact of Europeanization at the national and local level. It is worth noting that these principles are also at the heart of 'Europe 2020', a political strategy based upon advocacy and network building.

This article explores some of the challenges entrenched in the study of civil society engagement and interest representation in Europe. Our analysis is first and foremost interested in understanding the interaction between dominant policy discourses (coming mainly from, e.g., the European institutions and policy actors) and the emergence of counter narratives (from, e.g., civil society organizations) at the national and European level. The approach adopted by this article is discursive in nature, but it is also sensitive to the importance of content and context. We locate our discussion of the development of organized civil society (OCS) in Europe within the context of current debates about democratic accountability and the establishment of a European public sphere (EPS). Positioned at the interfaced between national and European politics, civil society organizations play a key role in promoting political engagement. The increased interest in OCS at the European level also indicates recognition of the role these organizations play in promoting the project within national communities. The analysis presented in the empirical section of this article highlights strengths and weaknesses of this political strategy for enhancing democratic ownership of the European project. The development of active citizenship - both as a coherent policy area and as a vehicle for increasing the engagement of traditionally marginal groups - provides useful insights into institutional strategies for dealing with the crisis of Europe and the rise of popular opposition to the European project.

Our article thus looks at four issues: 1) Institutional and non-institutional strategies for enhancing participation and reciprocal communication; 2) Plans for enhancing the reach of these strategies; 3) Implications of active engagement and civil dialogue for democratic governance in Europe; 4) Opportunities and constraints entrenched in these practices.

Commented [R2]: Who is this?
CB Added in footnote
Commented [R3]: which treaties?
CB added




\section{Understanding Civic Engagement and Participation: Methodological Considerations}

Our approach to policy analysis produces a form of policy tracing, not dissimilar to the work conducted by the MAGEEQ project (Verloo, 2005). We are foremost concerned with how values and norms play a role in the construction of the agenda and the mechanisms for involving different institutional and non-institutional policy actors. We developed a model of discourse analysis that integrates insights from poststructuralism as well as critical discourse analysis. In regards to the former, we looked at the importance of power relations in framing the interactions between various policy actors and their competition to shape meaning on specific policy concepts that become discursive nodal points (DNPs). In regards to the latter, we looked at the importance of political context in shaping DNPs, and in orientating the political strategies of public institutions.

The development of a networked territorial space is a consequence of the current processes of transnationalization. Social constructivists have claimed that it was necessary to find ways to unpack the EU's transformative effect on social realities (Christiansen, Jorgensen \& Wiener, 1999). This can be achieved by looking at the dynamics and discursive interactions between constellations of strong, transnational and weak publics. These networks contribute to the transformation of identities, cognitive schemas and structures of meanings for individuals. In turn, this process does not entail a passive adaptation to the forces of Europeanization, but instead interacts with conflictual and fragmented structures.

Discourse analysis is increasingly being adopted by social scientists as a useful tool for understanding the complexities of social and political structures (Diez, 2001; Dryzek, 2008; Howart \& Torfing, 2005). This approach looks at the role of language and communications in shaping the social world and, in turn, influencing the formulation of social policies. As Hajer argued, '[D]iscourse is defined as an ensemble of ideas, concepts, and categories through which meaning is given to phenomena. Meaning is thus produced and reproduced through an identifiable set of practices"' (Hajer, 2002, p. 63). For the purpose of this article, discourse analysis is a useful tool as it looks at the interaction between different publics, the reciprocal dynamics of power and the establishment of specific argumentative strategies formulated to impose a certain meaning on social reality (Liebert, 2007).

There is a growing body of literature on governance that is gradually replacing 'state centric' approaches to public policy analysis. These new approaches take into account new sites, actors, and themes in the development of key policies and their objectives. In referring to Castells's thinking on the network society, Hajer and Wagenar (2003) emphasize a shift in the language from 'institutions to networks', underlining the complexity of policy making which is increasingly framed by a wide set of competing social actors vying for a voice in the public arena. In these terms, discursive approaches require an understanding of the structures of power and systems of meaning prevailing at the different levels of the EU as a system of governance (Ingram \& Schneider, 2008). This approach is particularly useful for the analysis presented here as it allows us to assess how institutional and non-institutional discourses compete to shape meaning of European democratic governance.

A central question in discourse analysis is therefore the issue of power. Unpacking how power is articulated and manipulated is essential to understand the following: first, who imposes specific meanings on social realities; and second, who participates (or not) in framing public discourses. In fact, different, and often 
competing, discourses are articulated at the same time, challenging each other and often overlapping each other. From the position of the policy analyst, discourse analysis aims to understand why particular meanings become dominant and authoritative, while others are discredited. Diez (2001) refers to Europe as a 'discursive battleground', to represent the idea of the different and simultaneous struggles for shaping meaning on public discourses related to key concepts such as governance, citizenship, public sphere, identity etc. From his position, DNPs are 'central concepts in the political debate around which meaning is stabilized' (Diez, 2001, p. 16), whose meanings are fixed by a set of discursive practices and metanarratives through articulation (Laclau \& Mouffe, 1985).

\section{INSERT Figure 1 HERE}

As Figure 1 shows, DNPs are defined in our approach by a combination of variables such as context, policy priorities and meta-narratives. We argue that active citizenship as a European Commission-sponsored policy is introduced into the agenda because of the combination of four DNPs: 1) Democratization and public sphere; 2) Europeanization and transnationalization; 3) Political participation and civil dialogue; and 4) European social dimension. The discursive bargaining that takes place between a number of institutional and non-institutional actors in order to shape meaning - thus the DNPs - provides useful insights on convergence as well as fragmentation in the agenda-setting mechanisms at EU level. We argue that this process is best explained by focusing our discussion on the development of the European public sphere and the role played by civil society organizations in its constitution.

\section{European Identity, Civil Society and Public Communication Management: Constructing the Public Sphere}

The normative debate about the European public sphere (EPS) concentrates on whether this is a feasible reality at the European level. There is agreement in the literature that the existence of a public sphere is important because it entails discussion, interaction and the development of discourses on questions of public concern (Eriksen \& Fossum, 2000; 2002). It is a social construct that drives democratization and at the same time, as some critics of the Habermasian model (1989) argued (see for instance Fraser, 1992; 1995), it entails confrontation and fragmentation between dominant discourses and counter-discourses produced by different social actors, such as ethnic minorities (Schulz-Forberg, 2010).

According to Calhoun (2003), the development of a 'properly' European public sphere is important because it enhances the base for participatory democracy, something seen as necessary to address broader issues of democratic deficit and legitimacy (Bellamy \& Castiglione, 20001; Kohler-Koch \& Rittberger, 2007). The absence of a truly European public sphere is thus considered to reflect a lack of public support for the project as a whole. It is perhaps worth underlining here that the debate on the development of the EPS ran parallel to the famous confrontation between Habermas (1995) and Grimm (1995) that generated a new body of scholarship looking at the development of a transnational public sphere. More specifically, it looks at issues such as the Europeanization of the media, political

Commented [R5]: I may have torn up the meaning in order to avoid repetition of 'refers to'..

$\mathrm{CB}$ it looks perfect

Commented [R6]: 2000 in references.

CB Corrected

Formatted: Font: Italic 
communication, and the framing of European public opinion (Díez-Medrano, 2003; Statham, 2007; Trenz, 2010).

It is also worth noting the potential impact of a European political space on shaping the social imaginary, which results from improving dialogic communicative practices in the EU. As a result of this process and 'sponsorship', the European imagined community is to be conceived of as a top-down - and elite-centred/driven construction (Shore, 2000; Guerrina, 2002). It is not by chance that policy makers and eurocrats have concentrated on identifying agents of European consciousness; these are the actors that will advance/promote the development of the EPS and European identity more generally (Bee, 2010).

The process of constructing a European identity therefore requires the establishment of a social imaginary linked to a sense of Europeanness. A key requirement for the success of this process is the establishment of awareness-raising mechanisms designed to highlight the benefits of the European integration process. European institutions funded a range of programmes aimed at developing transnational social spaces with a European dimension, thus hoping to develop the collective imaginary required for the construction of a common identity. It is worth remembering the large set of EU-funded initiatives that enhance ties between different groups or collectivities (e.g. cities, regions and municipalities) in the fields of cultural, educational and social policies. Research on European cities of culture has highlighted how transforming urban spaces can influence the development of a transnational reality with clear European connotations (Sassatelli, 2009).

The main concern of this debate revolves around the social dimension of the European project. Clearly, civil society has a key role to play in fostering the development of a sense of solidarity at the European level. Calhoun (2002) understands the public sphere as a form of social solidarity, which is discursively produced and reproduced by the exchange between citizens and institutions. Pivotal in this process is the ability to foster the development of a social imaginary based on a shared sense of belonging to a territorial, cultural and political space. Key actors in this process are non-state actors promoting equality and social inclusion at the European level (Ruzza, 2004). It is in this context that we can see how the development of a 'properly' European public sphere is essential for mutual recognition and social cohesion.

Clearly this debate provides the backdrop against which European policy actors - both institutional and non-institutional - can maximize opportunities for influencing the policy process. In this context, questions about feasibility and 'reproducibility' of state-centric models of public sphere have become more poignant (Harrison \& Wessels, 2009; Schlesinger, 1999; Van de Steeg, 2002). The absence of a common media, shared language, and shared political culture works against the establishment of a homogenous EPS. The presence of wide-reaching interest representation at the European level through an eclectic civil society is often seen as a disadvantage (Bellamy, 2010; Scharpf, 1998). Focusing predominantly on the national polity as the locus of citizenship practice, these arguments neglect, or dismiss, the existence of a pan-European public sphere. Eriksen accepts that a nationally bound public sphere is no longer feasible, but argues that 'the European public space is currently fragmented, differentiated and in flux' (2004, p. 18).

Policy networks, new social media and civil society organizations are drivers in the constitution of a networked public sphere based on discursive interactions. By the very nature of the actors involved, these interactions are taking place at different levels of European governance. They have different capacity for influence and 
exchange at the European level; however, they come together to give meaning to a European social reality in what Diez (2001) calls the 'European Discursive Battleground'.

The development of a system of networked governance is shaped by the process of Europeanization that allows for transnational interactions and exchange. What emerges is a complex picture, not like Castells's (1996) vision that the EU is a networked society, but more closely aligned with Schlesinger and Kevin's (2000, p. 217-218) model of multilevel governance. They claim that a better - more realistic way of applying the concept of public sphere to the EU is by taking into account the interactions of the multiple publics and actors at work within this transnational polity. Schlesinger (2003) goes on to explain how these different actors and polities act inside the European communicative space. He deduces that this space is increasingly constituted by networks in which different actors interact and exchange information (cf. Koopmans \& Pfetsch, 2003; Trenz \& Eder, 2004). The interaction - often competition - between transnational and national interests shapes how power is allocated in the development of the EPS. The institutional structure of the EU reinforces the development of strong and weak publics that are often oriented towards representing the interest of national polities (Schlesinger, 2003, p. 1). In this context, the EU could be understood to be a body charged with the development of a social communication platform designed to connect different spheres and polities (Schlesinger, 2003, p. 4). As it will be shown in the rest of this article, this process is not linear but implies the production of fragmented and often opposing discourses. Civil society organizations have a significant role to play in helping European institutions in the process of identity building. Through this process they become the vehicle through which the EPS is created - thus contributing to the dissemination of the dominant, institutionally based discourse - as well as being the actors responsible for the formulation of counter-narratives.

\section{Actors in the EPS: The Role of the Organized Civil Society (OCS)}

The extensive body of literature on European civil society concentrates on institutional dynamics and structures. Of particular interest to the analysis presented here are those projects looking at political socialization and institutional cultures (Warleigh, 2001) and the Europeanization of civil society (Ruzza \& Bozzini, 2008). The interplay between institutional and non-institutional actors at the European level has also been of particular interest to scholars looking at the changing nature and role of civil society in Europe. The analysis of lobbying practices in and towards Brussels is particularly useful in understanding the context within which organized civil society (OCS) operates (Coen, 2007; Greenwood, 2007; Sanchez-Salgado, 2007).

Organized civil society can be defined as that group of non-stateinstitutional actors which have a direct and formalized relationship with European institutions. It includes non-governmental organizations (NGOs), social movements, advocacy groups, charities, representatives of self-help organizations and promotional groups (Ruzza, 2004). The power of these organizations has grown considerably in the networked system that is the EU (Kohler-Koch \& Rittberger, 2007; Smismans, 2006), where power is dispersed along different nodes and governance structures that are no longer bounded by state sovereignty (Warleigh, 2001).

This process, however, has generated two competing spheres. On the one hand there are highly institutionalized civil society organizations that work within formal 
structures and networks as discussed above. On the other hand, a number of critical forces, such as social movements, have started to emerge. These new social actors use the EPS in a way that is more fluid and non-institutionally bound. It is the latter group that is increasingly responsible for producing a critique of Europeanization (Della Porta, 2009). The development of transnational protest and interactive practices in arenas such as the European Social Forum are prime examples of civil society organizations producing counter-narratives and alternatives to institutional practices (Balme \& Chabanet, 2008; Saunders, et al., 2009). The distinction between types of civil society organization is important here because it helps us to understand how they facilitate - or not - the establishment of a European polity. If we assume that OCS is key to the development of the EPS, then understanding its interaction - however complex - with institutional structures is essential to explain how it facilitates ownership and engagement amongst traditionally marginal groups.

More specifically, by conceptualizing the fragmentation of the EPS in networks, discourses and spheres of publics we can look at distinct claims about how interests are represented at different levels of European governance. The asymmetrical influence also exercised by different groups over policy-making processes also helps us to understand how power manifests itself within network governance. As we have already established the EPS is a top-down, elite-driven process; it is thus worth remembering that, over time the EU has sought to address such concerns by developing an approach to public communication that involves social actors (such as the civil society and the media) as well the general public.

The White Paper on Communication (CEC, 2006) and Plan D (CEC, 2005) represent a critical junction for the way European institutions manage this process. Firstly, these policies enhanced the EU's capacity to communicate about transnational issues. Secondly, and perhaps more importantly, they also transformed public campaigning from an activity into a public policy. They sanctioned a formal budget for this policy area and defined specific priorities and spheres of intervention. We can easily find examples of how these policies have been implemented by looking at the main EU communication campaigns of the last five years, e.g. social communication on 'sensitive issues', like health, global warming, the environment, antidiscrimination and gender equality At the same time, European institutions have also sought out the involvement of non-state actors in the development and execution of the actual campaigns. This model is known in public communication theory as the 'symmetrical model of public relations' (Fawkes, 2004; Grunig \& Grunig, 1992). In a nutshell, it is based on the enhancement of mutual, interactive and dialogic relationships between institutional and non-institutional actors in constructing the public discourse on issues of public interest.

It is worth noting that institutional communication is a public relations activity and a way of producing public communication. It can be defined as a set of activities organized by institutional actors on questions of public concern, which entails several closely aligned elements. Firstly, institutions have an agenda setting role to play, in as far as they need to decide what needs to be communicated. Secondly, the institutions need to enable interaction between citizens and policy makers. Thirdly, there have to be opportunities for feedback on policy proposal interventions organized by public bodies. Finally, citizens have to be able to influence and change institutional activities throughout feedback process. The basic assumption that underpins this process is that a fully democratic political system must find a way to develop open and accessible communication tools. 
Figure 2 illustrates the interactions between public institutions, citizens and 'mediators' in what is a bidirectional model of communication (Mancini, 2003). Public institutions produce outputs on questions of public concern that target sectors of public opinion and/or specific target groups. In this model, communication is achieved through the exchange between citizens and public institutions whereby the citizens - or specific targets groups - contribute by providing input into the process in order to redirect or stabilize public policies. The discursive battleground is located at the interface between institutionally sponsored public information campaigns - i.e. top-down - and citizens/civil society - i.e. bottom-up - responses to the policy process. This model implies some kind of discursive encounter or struggle to legitimize the process. As such, it is most effective when bottom-up inputs reach policy makers, thus signalling participation and representation. The model therefore hinges upon the ability of the 'mediators' - i.e. civil society organizations - to engage with the public institutions; the pressure they levy on these public institutions and the way they represent citizens' interests ultimately shape the scope and reach of the final policy outcomes. The idea of active citizenship becomes particularly relevant in this discussion, in as far as it allows citizens to engage directly with policy makers, and without the intervention of mediators, for the pursuit of a common interest. Our article focuses specifically on the bottom-up responses to official policy documents and public information campaigns. It therefore looks at the effectiveness of OCS as a moderator in the process and a vehicle for citizens' participation and representation.

The work carried out by the PIDOP project, particularly in the context of understanding current policy approaches to improving political participation and engagement, shows that application of this ideal model of institutional communication at the European level is challenged by various factors, above all, the complexity of European governance, the dispersion of power between different levels and the existence of strong, transnational and weak publics. These variables ultimately contribute to the creation of multiple polities with unbalanced access to European institutions. Our analysis shows that the development of a mutual, transparent, symmetrical and bidirectional model of institutional communication favours interactions between strong and transnational publics, at the expense of weak public spheres. Awareness of the biases at the heart of European communication policy and its application to active citizenship therefore calls for a detailed analysis of the impact these processes have on the establishment of active citizenship at the European level.

\section{Active Citizenship in the EU: Unpacking the Discourse}

Our projectThe PIDOP project focused on key policy development in the area of active citizenship and participation at the European level between 2004 and 2010. We have been particularly interested in how these policy trends shaped the political agenda of the erganization as a wholeEuropean Commission and how OCS responded to institutional efforts to increase political participation and representation of traditionally marginal groups.

The EU has always been a magnet for wide range of civil society organizations seeking to lobby and influence European institutions. The very nature of European governance encouraged the participation of organized civil society in a supranational setting. Umbrella organizations - e.g. Social Platform, CONCORD, the European Youth Forum, and the European Women's Lobby - act as catalyst for the

Commented [R11]: does this mean without the 'mediators'?
That's what it implies.
CB I added a line, I hope it is clearer now

Commented [R12]: Do you mean 'the PIDOP Project'?

CB Yes, added

Commented [R13]: the European Union? the European Commission? 
engagement of a wide range of social interests at the European level. They have a privileged position in the Brussels arena and thus they are an example of a strong public looking to represent the interests of transnational organizations connected with them. However, questions need to be asked about their own accountability and how effective they are at representing weaker publics such as NGOs, associations and organizations that operate at the sub-national levels. Concentration of power and access in the hand of strong transnational umbrella organizations ultimately reduces the opportunities for weaker groups to influence public policies and to make their voices heard at the European level. This asymmetrical structure challenges a core assumption at the heart of European approaches to active citizenship, i.e. that OCS can and/or should act as legitimizing force for the EU.

This section will unpack this complex set of interactions, thus contributing to current debates about governance, legitimacy and democracy in Europe. The section will focus on European OCS in an attempt to assess how the extent to which these groups have become institutionalized and therefore agents of European political communication, as opposed to active representatives of a counter-discourse.

Our analysis concentrates on the range, scope and depth of interactions between OCS and the European Commission in order to uncover these organizations' influence on the development of the European policy agenda. In order to account for the asymmetrical development of structures for active citizenship, we selected a number of policy documents produced by the European Commission in the period 2004-2010. The large number of public campaigns initiated by the Commission in the period between 2004-2010 is a direct consequence of Plan D and the White Paper on Communication Policy. These campaigns are particularly relevant for the PIDOP project because of their focus on minority rights, social exclusion, anti-discrimination, poverty, intercultural dialogue, equality, and similar topics. The intention is to unpack the direction of travel or trajectory of European strategies for civil society engagement during the Barroso I presidency. In keeping with the focus of the PIDOP project, we concentrated on three categories of citizens (i.e. youth, women, and migrants and minorities). Four DNPs emerged from the wider European political context and the analysis of these documents. These DNPs are significant for our discussion as they frame European institutional discourse on political participation and civic engagement. The next step in our research was to select and analyse an equal number of policy documents produced by supranational umbrella civil society organizations, e.g. the European Youth Forum, the European Women Lobby, the Social Platform, Concord, Euractiv, Enar and Solidar ${ }^{2}$.

Our sample was then examined to assess the development of policy narratives around the concept of active citizenship, which is the main analytical frame for this article. The analysis to follow therefore looks at the development of active citizenship, as it is linked to four key discursive nodal points (DNPs) (see table 1 below). The article thus sets out how active citizenship was introduced as a policy objective and how it relates to specific policy actions (e.g. policy programmes such as Youth in Action or legislative instruments such as Art. 11 of the Lisbon Treaty).

\section{INSERT TABLE 1 HERE}

Four DNPs emerge as dominant, each supported by various meta-narratives e.g. European identity, future Europe, and euro-crisis. The specific political context that characterized European integration between 2004 and 2010 - e.g. the rejection of
Commented [R14]: or 2004 as in previous sentence? It seems odd to have 2004-2010 in one sentence and 2005-2010 in the next.

$\mathrm{CB}$ yes, corrected

Commented [R15]: Since there are 4 items listed here but only three categories of citizens, I assume 'migrants and minorities' belong together as one category. If this is not the case, please revise accordingly keeping in mind that the number of items and number of categories should match.

CB Yes, minorities and migrants in PIDOP were considered as a single category 
the Constitutional Treaty, enlargement, the ratification of the Lisbon Treaty, the publication of Europe 2020, etc. - defines these narratives and discourses by promoting specific political priorities, such as the development of an open and transparent EU based on the participation of civil society. The rest of this article will look at how OCS responded to institutional discourses on active citizenship and whether it was successful in advancing a counter-discourse. The analysis is particularly insightful as it provides evidence of the range and scope of critiques advanced by umbrella organizations in Brussels. The focus of these counterdiscourses is specific policy initiatives aimed at improving active citizenship and civic engagement. Overall, it traces how the DNPs become sites of contestation for noninstitutional-state actors. When taken together the meta-narratives produced by the OCS in relation to the DNPs challenge dominant discourses on active citizenship proposed by the European Commission.

\section{Democratization and Public Sphere}

The European Commission's response to the rejection of the Constitutional Treaty in 2005 indicates institutional recognition of the need to improve the democratic foundations of the European project. From this point the Commission makes a concerted effort to enhance the basis of participatory democracy at the European level by increasing opportunities for interaction and exchange with the 'public'. This approach is also an attempt to develop a bidirectional model of public communication that feeds into the Commission's understanding of public sphere and governance.

It is important to unpack the Commission's strategy for dealing with one of the most significant challenges faced by the EU: popular rejection of the project. In response to the challenge laid down by emerging social forces, the Commission put forward a number of meta-narratives aimed at 'fixing' those dimensions of the EPS deemed to be undermining key institutional objectives. It adopted a set of argumentative strategies aimed at imposing a dominant discourse on the EPS. This process allows the Commission to take ownership of the concept - so that it becomes the EU's public sphere - thus stabilizing its meaning. This top-down process of construction of meaning is challenged by a wide set of counter publics that generate meta-narratives that challenge the very notion of an EU-dominated EPS. The productive exchange between institutional - i.e. dominant - narratives and noninstitutional discourses can be seen as a battle to establish meaning.

From this perspective the EPS is fluid and subject to discursive mediation, i.e. its meaning is not fixed and the subject will only stabilize when another dominant discourse emerges. It is worth noting that European civil society has widely challenged the notion of the public sphere proposed by the European Commission. Cited below is an example of counter-discourse offered by EurActiv (2006) after the publication of Plan D (CEC, 2005). EurActiv's Plan D: Diversify, Decentralise, Disseminate, Decide (EurActiv, 2006), challenges the Commission's vision of a homogeneous public sphere. In particular, EurActiv's argues for the establishment of a networked and decentralized approach:

The European public sphere is certainly desirable, given what some call the federalist vocation of the EU. But is it achievable within a reasonable time? (...) Rather, are there not multiple public spheres, fragmented by national and socio-professional canters of interest? If so, one should privilege 
interconnection of national spheres/benchmarking (...) rather than trying to create one European public sphere. (EurActiv, 2006, p. 5)

The interpretation of this 'struggle' to impose meaning on the concept of public sphere has to be understood in light of two other DNPs: 1. Europeanization and transnationalization; and 2. Political participation-and civil dialogue. EurActiv's position focuses on diffusion of leadership and power as a route to promote democratic governance at the European level.

EurActiv's meta-narrative is driven by an overarching aim to account for the role of transnationalization in the construction of the EPS. This position is intended to challenge the definition of the EU's public sphere as defined - or fixed - by the European Commission. In order to resist the discursive underpinning of the official narrative (DNP), EurActiv's articulation of a counter-discourse must be accompanied by specific mechanisms (e.g. civil dialogue) that guarantee open interplay (i.e. public communication) between institutional and non-institutional actors. It is worth noting here that the European Commission has substantially increased the opportunities for civil organizations to provide input into the policy making process. Open consultations on public policies are now fairly common practice and have greatly enhanced the ability of 'counter publics' to influence and change the meaning of a DNP (Bozzini, 2007). There are two defining features to this process of engagement that ultimately impact upon the quality of interest representation at the European level. Firstly, consultation is now an intrinsic part of the EU's communication strategy. Secondly, official communications and consultations are largely directed at strong and transnational publics.

Debates about the most appropriate ways of communicating to marginal groups in order to enhance ownership and participation at the European level is a recurrent concern of many policy documents we analysed. This process of contestation highlights the OCS's perceived ambiguity in the development of the EPS. It also points to an increased fragmentation and contestation of the vision put forwards by the European Commission.

Despite increased recognition that the EU can be a catalyst for change in social matters, there is also a sense that it has to compete with other - perhaps more powerful - sources of information. Take for instance the representation of minority groups in the media; European public discourse on equality and diversity is in direct competition with sources of information that are more accessible by the public. The limited reach of the EPS and its competition with national political narratives ultimately undermine the effectiveness of European policy initiatives. The European Network Against Racism's (ENAR) assessment of EU project to fight racism highlights this tension:

Many ethnic and religious minority groups have been affected by public perception and the negative debate on migration. The negative portrayal of migration by policy makers and by the mass media through stereotypical language and negative images has led to a worrying increase in racism and xenophobia towards third country nationals. (ENAR, 2008, p. 1)

In this extract, ENAR identifies public representation of minorities by the media and some sections of the political sphere as one of the drivers for social exclusion and discrimination in Europe. The organization considers it to foster stereotypes of the 
strong public sphere (i.e. the majority groups) towards the weak one (i.e. minorities). On this account the organization in fact remarks that:

The media continues to have a major influence on the perceptions of minority communities. [...] The conspicuous lack of minority representation in all forms of media also creates a misperception, especially when the only representation is negative stories and stereotypes. News stories will often identify the ethnicity or origin of those perpetrators who are foreign or belong to a minority community, in contrast to when a member of the majority population commits a crime. (ENAR, 2010, p. 12)

Together these extracts highlight some of the recurring themes associated with current debates about transparency and accountability at the European level. They also stress the challenges entrenched within an asymmetrical communication structure whereby European public institutions are reliant on Member States and civil society organizations for dissemination and engagement. Lack of a European media and/or meaningful engagement with transnational issues is the main problem for the establishment of a European political space. On this account, we can thus underline the emergence of a number of challenging issues that are put forward by the OCS in answer to the European Commission's project to shape the EPS.

\section{Europeanization and Transnationalization}

Focusing on European-level discourse highlights the increasing centrality of the processes of Europeanization and transnationalization. The relationship between national and European NGOs is a recurrent theme that emerges from the analysis of civil society documents. The asymmetrical relationship between these two levels and the ability of the latter to represent the interest of national groups has been a central point of discussion. Weaker groups' exclusion from strong European networks reduces their capacity to influence public policies. The power of European level OCS to act as gatekeeper needs to be recognized, if issues of legitimacy and representation are to be addressed in a meaningful way. This consideration is true of all OCS, but it is particularly important in relation to traditionally marginal groups as it defines the parameters for membership.

The process of Europeanization is not linear. Rather, it is fragmented both vertically (EU to member states) and horizontally (member state to member state). The way that this process affects civil society organizations is interesting because it highlights the complex web of interactions and tensions at the heart of European governance.

Civil society organizations thus serve a dual function. They are both a source of legitimacy for institutional meta-narratives, as well as the main source of opposition to dominant discourses. The organizations included in our analytical sample accept the values, policy objectives and political priorities identified by European institutions. In this context, they therefore legitimize the four DNPs emerging at the European level. At the same time, they distance themselves from institutional-the Commission's narratives by not engaging with the objectives of specific European programmes or core principles relative to the European integration process. It is interesting to note that reference to core policy meta-narratives 
addressed at the supranational level (e.g. constitutionalism or identity) rarely make an appearance.

Institutional-European Commission's attempts to bring civil organizations 'into the fold' are increasingly the object of reflection and critique. For example in December 2008, Social Platform launched an annual conference on Civil Dialogue How can we shape the Europe we want? Hard to reach communities across Europe were the subject of much debate. Empowerment, improvement of information flows at the local level, enhancement of education and opportunities for communities are some of the key tasks transnational NGOs agreed to take on (Social Platform, 2008). This response sought to address concerns about the inclusiveness and representation of European level civil society organizations. It is also a good example of the bottomup dynamics started by grassroots organizations to demand better representation in policy processes.

The socio-economic conditions of specific groups influence access to power and decision-making mechanisms. This is true at the national level, but it is an even more poignant consideration when thinking about European governance. The complexity of European processes increases the distance between policy actors and citizens. This is particularly true of traditionally marginal groups that rely on civil society organizations for interest representation and access to political institutions. The European Youth Forum's (EYF) narrative reflects these concerns. When looking at the integration of 'young people with fewer opportunities', the Forum points to the extent to which this group is excluded from the civil dialogue and, to a large extent, the exercise of active citizenship. EYF is particularly critical of EU youth policy (Youth in Action):

Young people with fewer opportunities and small youth organizations do not have the capacity to build the knowledge necessary to benefit from the Youth in Action programme and from most of the EU programmes (...). The European civil society should be strengthened by including a truly European level within the programme and a recognition of the status of European youth organizations who are the main channels through which young people interact structurally with the EU democratic process (EYF, 2010a, p. 5).

EYF's criticism concentrates on mechanisms for engagement. It highlights the crucial role played by OCS in facilitating access to institutional structures. EYF's work on strengthening transnational cooperation provides evidence of a process of Europeanization, whilst also highlighting the linchpin role played by OCS in mediating between the national and the European level. We explore this in more detail in Bee and Guerrina (2014) where we look at how social problems - e.g. poverty, racism, unemployment, discrimination, social exclusion - negatively affect the ability of weaker groups to participate and engage in the process of Europeanization.

\section{Political Participation and Civil Dialogue}

Brussels-based organizations have long recognized the importance of developing some form of civil dialogue ${ }^{3}$ and have sought to promote active citizenship as a policy rather than just a set of practices involving interactions between citizens, national and transnational organizations, and European institutions. In practice, however, national NGOs struggle to establish coherent patterns of representation, which ultimately 
limits their influence at the EU level. It is worth noting that European-level civil society organizations have been elaborating specific dialogic instruments to facilitate interest representation at the supranational level.

Our analysis of civil society statements and policy documents highlights the centrality of civil dialogue. This process has an enabling function in as far as it facilitates access to actors within the EU institutions and allows direct input in agenda-setting mechanisms. It guarantees transparent interplay between EU institutional actors and NGOs and enables the exercise of active citizenship. As Social Platform recently stated: 'Civil dialogue is a concrete tool to strengthen the relationship between public decision makers and CSOs' (Social Platform, 2010). This is thus a formal instrument through which NGOs lobby, frame claims and establish a dialogic relationship with the policy makers. It is therefore meant to establish a bidirectional model of institutional communication at the European level.

Recognition of civil dialogue as a core practice for European governance came with the inclusion of Art. 11 in the Lisbon Treaty, whereby:

The institutions shall maintain an open, transparent and regular dialogue with representative associations and civil society. (Art. 11.2)

The European Commission shall carry out broad consultations with parties concerned in order to ensure that the Union's actions are coherent and transparent. (Art.11.3)

Both these practices have long been a feature of EU policy making. However, inclusion in the Treaty provides a legal foundation; it reiterates the centrality of interest representation and fosters active citizenship as a core practice for the delivery of democratic governance at the European level. The European Network Against Racism (ENAR) welcomes this shift:

It is not only representative democracy which will be strengthened by the text of the Lisbon Treaty. The explicit adoption of the principle of participatory democracy is an extremely important innovation in the Lisbon Treaty from the perspective of advocacy groups working in the field of racism and xenophobia. (ENAR, 2009, p. 13)

Article 11 therefore provides a much needed opening for OCS to become formally involved in policy making processes. This is an important shift that paves the way for a wide range of interests and voices to find the way to the negotiating table. It also raises important questions about the very nature of European level OCS and interests represented within it. Increasing institutionalization of OCS is a clear opportunity to shape the policy agenda; however, it also carries the inherent danger that OCS will lose its critical voice.

It is important to recognize the potential of active citizenship and civic engagement; however, both practices should not be seen as being fully inclusive. For instance, in our sample, the OCS points at a number of issues that undermine the effectiveness of civil dialogue. A recurrent meta-narrative on this account points at the limited reach of Art. 11 in relation to weaker groups. Civil society's demands for more structured forms of dialogue and for the development of a symmetrical system of institutional communication have yet to be completely fulfilled. What is clear from 
this brief discussion is that OCS does not deem Art. 11 to be sufficient to bridge the participation gap affecting European governance.

In a 2010 report, the European Network Against Racism discussed 15 Principles for framing a positive approach to migration. Lack of inclusion and silencing of minority groups are key concerns of the organization:

The current process has been marked by a lack of dialogue and engagement with civil society. It is crucial that such a dialogue takes place as it is central to the development of a common European policy on immigration and asylum (...) In order to change the negative dynamic around the migration debate, the migrants' voice must be heard in EU and national decision making concerning migration policy. (ENAR, 2010, p. 5, 11)

In a similar vein, a European Youth Forum policy paper looking at the issue of Young People and Poverty highlights the condition of disadvantaged groups and at the possible policy responses in order to improve their social inclusion:

Unfortunately, it needs to be said that poverty and social exclusion affect active citizenship, hinder participation and set barriers for volunteering. Youth organisations, in their daily activities often, contribute to the activation and empowerment of young disadvantaged people that can eventually allow them to break away from the vicious circle of poverty. (EYF, 2010b, p. 10)

These extracts highlight two issues that are important for the analysis presented here: First, OCS is uniquely positioned to provide a platform for interest representation and inclusion. They are the critical voice of European policy making. They serve a key function in articulating counter-discourses and narratives, thus providing checks and balances for institutional agendas. Second, the inclusion of OCS into formal processes allows greater influence on policy making at the agenda-setting stages; however, it also dilutes its ability to exercise its role as a critical voice.

\section{European Social Dimension}

What emerges from the analysis of the previous nodal points is that civil society organizations identified the need to develop a European social dimension as a top policy priority for the future. This umbrella concept allows for contestation of key values underpinning the process as a whole. It therefore becomes the discursive battleground identified by Diez (2001).

Social policy forces institutional actorspublic institutions to address questions that are normative in nature and outcomes. Issues like sustainability, gender equality, health promotion and anti-discrimination require detailed consideration of the foundational values of the organizations, how key actors adopt and promote these values, and the limitations of specific strategies. Focus on the social dimension therefore provides an opening for OCS to raise questions about the applicability of the key institutional narratives and delivery mechanism, e.g. the Lisbon Strategy. This process of exchange, challenge and reframing allows both institutional actorspublic institutions and civil society to refine their position, aims and role within the European policy-making process.

Formatted: Highlight

Formatted: Highlight 
It is important to note that a number of Brussels-based organizations advocate the development of a European social dimension based on the principle of equality. Despite the inclusion of this principle in the founding treaties, its development in subsequent iterations of the treaties, a large body of secondary legislation and public statements that place equality at the heart of the integration process, our analytical sample produced a number of significant criticisms of the approach adopted by the Commission in the implementation of this principle. For example, commenting on the Barroso II presidency, the European Women's Lobby:

Equality between women and men is a fundamental right and value of the European Union and should be central to all Commission initiatives, policies and programmes. It is a legal, moral and economic imperative, not a luxury to be addressed sporadically or only during times of prosperity. While some positive steps are being prepared in this area - including a new Commission action plan on equality between women and men which will hopefully give flesh and bones to commitments - so far, the Barroso II Commission's performance has been disturbingly mixed, and concrete actions in favour of a more equal society have been few. (EWL, 2010)

The EWL's position provides a test for the Commission's rhetoric/narrative, particularly when the dominant perception is that it has not been accompanied by substantive action. It also highlights some of the limitations of a social agenda that is deeply normative in nature but is operating in a political context where the polity is largely absent and policy makers are seen as setting the agenda for social change.

Of particular concern to organizations like the European Women's Lobby, the European Network Against Racism and the Social Platform is the issue of intersectionality. Mainstreaming the specific social needs and social problems affecting different minorities into European policies, thus becomes a top priority. The EWL's contribution to the consultation on the Roadmap for Gender Equality and the follow-up strategy makes this position very clear:

One of the related challenges has been that the gender angle is often forgotten in policy areas that are not seen as related to gender equality, e.g. disability, Roma inclusion or integration, migration and asylum, while in turn this other policy angle is overlooked in gender equality policies. This shows the need to increase policy coherence and effectively monitor gender mainstreaming in other policy areas while there is also a need to strengthen the intersectional approach in the new Strategic Action Plan (...). Without the effective implementation of an intersectional approach, the specific needs of some groups of women (...) might be overlooked in the policy areas covered by the Strategic Action Plan. (EWL, 2009, p. 4)

This extract highlights increasing concern with the approach of European institutions that seem to adopt a very one-dimensional view of equality. With preferential access to the Commission the EWL therefore provides a very useful source of - constructive - critique for European political institutions. What is significant here is that these shortcomings remain central to gender governance despite the fact that equality between men and women is also one of the most developed areas of European social policy (Guerrina, 2005) and the EWL has a long-standing relationship with the European Commission and the European Parliament. 
Remaining on the issue of anti-discrimination, the European Network Against Racism states its position in relation to the challenges that different minority communities have faced in gaining support and recognition at the European level:

The only area of anti-racist work which has received specific high level political attention has been the particularly hostile social and economic conditions in which the Roma, especially in the new member states of central and Eastern Europe, find themselves. Consequently, the incorporation of equality mainstreaming, including the mainstreaming of anti-racism, in the Lisbon Treaty, represents a significant strengthening of the existing legal basis for current practices and for policy-making. (ENAR, 2009, p. 12)

In this context ENAR's work focuses on identifying the limitations of current policy discourse. Similar to the previous example, the role of this civil society organization is to act as a 'critical friend', working closely with institutional bodies to improve policy outcomes. There is little evidence, however, of how these criticisms have been folded into the actual policy process. ENAR and EWL also have preferential access to European institutions, which on the one hand provides a platform to influence directly the policy process but on the other positions them as the dominant voice of each group at the European level.

Some policy priorities surface that require urgent attention: enhancing intercultural dialogue and the establishment of common antidiscrimination frameworks across EU and non-EU states; recognition of disadvantaged groups - e.g. ethnic and linguistic minorities, women and youth from minority groups - by guaranteeing access to education and the labour market; development of policy frameworks in the areas of healthy living and sustainability; and the establishment of concrete measures regarding social Europe.

Given the shortcomings of the EPS, the most effective way to communicate with the polity is within a national framework. Key information campaigns and education programmes need to be established by national institutions to facilitate public communications on issues like gender equality, rights of minorities, possibilities to access the labour market, etc. The recent Euro-crisis and associated debates about the reach and depth of austerity are poignant examples of the importance of public communication and the dominance of national public spaces. Key drivers of social Europe, such as social solidarity and social cohesion, are questioned and reframed in this context.

In thinking about the process of polity building in which the EU is currently engaged, the development of a European social dimension is central to the long-term success of the project. Yet policies coming under this broad umbrella still lack visibility. One obvious conclusion is that political institutions must improve public communication measures at the national level. This is, however, unlikely as official communication will inevitably fall between European and national interests. Improving the engagement and access of national NGOs in the supranational setting is likely to be a more effective strategy. Civil society organizations thus become the vehicle for public communication.

\section{Conclusion}


This article has looked at the role of civil society organizations in European governance. Our analysis highlights that organized civil society is not only a central actor in the European public sphere, it also plays a fundamental role in respect to European democratization and constitutionalism. The diverse set of interests it represents, or attempts to represent, widens the bases for political participation and representation at the European level. OCS plays a key role in shifting and readdressing the EU's policy making on questions of public interest and for developing transnational forms of social solidarity.

The development of a networked EU and the growth in the role and importance of non-state actors is strategically oriented towards the debate on the EPS. As explained in this article, this is constituted by a constellation of actors that elaborate diverging and conflicting discourses at different levels. In the European discursive battleground (Diez, 2001), different publics struggle to shape meanings on the social reality, to influence the policy making and to frame the public policies. The final section of this article highlights the asymmetrical nature of OCS. Brussels-based organizations are an expression of a strong public, representing transnational actors and attempting to include the sub-national and weak publics. The EPS that emerges in this process favours interest representation through strong civil society organizations. The downside of this approach is that the organizations become socialized and institutionalized through the exchange. The capacity of these organizations to formulate a counterdiscourse, thus expanding the reach of democratic governance in Europe, is therefore diminished.

It has been argued that the emergence of the EPS is contextual to the emergence of a debate about the feasibility of a model of institutional communication. This ambitious project was a reaction to the rejection of the Constitutional Treaty in 2005 and of the Lisbon Treaty in 2008. It is based on the assumption that the democratic deficit arises from a communication deficit. This reflects the process that followed the draft of the White Paper on Governance in 2001, when the European Commission declared that "the aim should be to create a trans-national "space" where citizens from different countries can discuss what they perceive as being the important challenges for the Union' (CEC, 2001, p. 12). At that time, Eriksen (2001, p. 2) commented ' $[\mathrm{B}]$ by focusing on apathy and ignorance, one not only puts the blame on the people, but also reduces the problem to one of information - it is about lack of knowledge. This represents a rather superficial understanding of the causes of the distrust, and one which, nevertheless, remains at odds with the post-Nicedebatefocusing on apathy and ignorance one not only puts the blame on the people, but reduces the problem to an information problem it is about lack of knowledge. This represents a rather superficial understanding of the causes offor distrust, and one that is at odds with the post Nice debate'. Popular rejection of the Constitutional Treaty in 2005 supports Eriksen's criticism of the Commission's approach. However, this time the Commission's efforts to foster active citizenship must be acknowledged; they resulted in the drafting of public policies in areas like health, gender equality, environment, global warming and anti-discrimination.

This public policy approach is based on 'a citizen-centred strategy'. This is supported by the development of a Europe-wide, homogenous public sphere Unfortunately, this approach suffers from a mis-conceptualization of the EPS and a tendency to favour national models. The strategy of the European Commission has not taken into account some of the main findings of current research on the EPS, e.g. the existence of fragmented and overlapping discourses, the fluidity of the processes of transnationalization, and the existence of different power structures that define

Commented [R19]: Either words or punctuation is missing here. CB I FOUND THE QUOTATION FROM THE ORIGINAL PAPER 
access to policy making and thus influence on the on the policy agenda. Ultimately, it disregards the diversity in European publics. The present scenario is characterized by the presence of a whole set of counterdiscourses going on in Brussels and entailing a continuous discursive confrontation between different publics in the struggle to fix a meaning on the practices of active citizenship.

\section{References}

Balme, R. \& Chabanet, D (2008) European Governance and Democracy: Power and Protest in the EU (Lanham: Rowman \& Littlefield).

Bee, C. (2010) Understanding the EU's institutional communication. Principles and structure of a contested policy, in: C. Bee \& E. Bozzini (Eds) Mapping the European Public Sphere: Institutions, Media and Civil Society, pp. 83-98 (Aldershot: Ashgate Publishing).

Bee, C. \& Guerrina, R. (2014) The Europeanisation of policy discourses on participation and active citizenship, in: M. Barrett \& B. Zani (Eds) Political and Civic Engagement: Multidisciplinary Perspectives (London: Routledge) (In publication).

Bellamy, R. (2010) Democracy without democracy? Can the EU's democratic 'outputs' be separated from the democratic 'inputs' provided by competitive parties and majority rule?, Journal of European Public Policy, 17(1), pp. 2-19.

Bellamy, R. \& Castiglione D. (2000) The uses of democracy: Reflections on the european democratic deficit, in: J.E. Eriksen \& E.O. Fossum (Eds) Democracy in the EU: Integration through Deliberation, pp. 65-84 (London: Routledge).

Bozzini, E. (2007) The role of civil society organisations in written consultation processes: from the European Monitoring Centre to the European Fundamental Rights Agency, in: V. Della Sala \& C. Ruzza (Eds) Governance and Civil Society: Policy Perspectives, pp. 93-109 (Manchester: Manchester University Press).

Calhoun, C. (2002) Imagining solidarity: Cosmopolitanism, constitutional patriotism, and the public sphere, Public Culture 14(1), pp. 147-171.

Calhoun, C. (2003) The democratic integration of Europe: interests, identity, and the public sphere, in: M. Berezin \& M. Schain (Eds) Europe without Borders. Remapping Territory, pp. 243-274 (Baltimore and London: The Johns Hopkins Press).

Castells, M. (1996) The Rise of the Network Society (Cambridge: Blackwell).

CEC (2001) European Governance: A White Paper, COM (2001) 428 final.

CEC (2005) The Commission's contribution to the period of reflection and beyond: Plan-D for Democracy, Dialogue and Debate, COM (2005) 494 final.

CEC (2006) White Paper on a European Communication Policy, COM (2006) 35 final.

Christiansen, T., Jorgensen, K.E. \& Wiener, A. (1999) The social construction of Europe, Journal of European Public Policy, 6(4), pp. 528-544.

Coen, D. (2007) Empirical and theoretical studies in EU lobbying, Journal of European Public Policy, 14(3), pp. 333-345.

CSCG (2006) Civil Dialogue: making it work better. Available at

http://www.stakeholders-socialinclusion.eu/site/en/tools/2006-1 September 2013).

(accessed 1

Della Porta, D. (2009) (Ed) Another Europe (London: Routledge). 
Díez-Medrano, J. (2003) Framing Europe. Attitudes to European Integration in Germany, Spain, and the United Kingdom (Princeton/Oxford: Princeton University Press).

Diez, T. (2001) Europe as a discursive battleground: Discourse analysis and European integration studies, Cooperation and Conflict, 36(1), pp. 5-38.

Dryzek, J.S. (2008) Policy analysis as critique, in: M. Moran, M. Rein \& R.E. Goodin (Eds) The Oxford Handbook of Public Policy, pp. 190-203 (Oxford: Oxford University Press).

ENAR (2008) 15 Principles for framing a positive approach to migration. Available at http://cms.horus.be/files/99935/MediaArchive/pdf/MigrationPublication_EN_L owres.pdf (accessed 30 March 2013).

ENAR (2009) The EU Lisbon Treaty: What implications for anti-racism? Available at http://cms.horus.be/files/99935/MediaArchive/publications/lisbontreaty_EN_L Rfinal.pdf (accessed 30 March 2013).

ENAR (2010) Combating Racist Crime and Violence: Testimonies and Advocacy Strategies. Available

at http://cms.horus.be/files/99935/MediaArchive/pdf/AdvocacyBooklet_EN_lowre s.pdf (accessed 30 March 2013).

Eriksen, E.O. (2001) Democratic or technocratic governance?, Jean Monnet Working Paper. Symposium: Mountain or Molehill? A Critical Appraisal of the Commission White Paper on Governance 06/01. Available at: http://www.eui.eu/Documents/RSCAS/Research/OnlineSymposia/Amstrong.pd f (accessed 23 October 2013).

Eriksen, E.O. (2004) Conceptualizing European Public Spheres: general, segmented and strong publics, ARENA Working Paper 3/04. Available at: http://www.sv.uio.no/arena/english/research/projects/cidel/old/WorkshopStirlin g/PaperEriksen.pdf

(accessed 23 October 2013).

Eriksen, E.O. \& Fossum, J.E. (Eds) (2000) Democracy in the European Union: Integration through Deliberation (London: Routledge).

Eriksen, E. O. \& Fossum J.E. (2002) Democracy through strong publics in the European Union?, Journal of Common Market Studies, 40(3), pp. 401-424.

Euractiv (2006) Yellow Paper on European Communication. EurActiv's Plan D: Diversify, Decentralise, Disseminate, Decide. Available at http://www.euractiv.com/29/images/YellowPaperFinal30September2006_tcm2 9-159859.pdf (accessed 30 March 2013).

EWL (2009) EWL Response to the Consultation on the Roadmap for equality between women and men 2006-2010 and follow-up strategy. Available at http://www.womenlobby.org/spip.php?article398 (accessed 30 March 2013).

EWL (2010) Barroso II and Women's Rights. Available at http://www.womenlobby.org/spip.php?article451 (accessed 30 March 2013)

EYF (2010a) Position Paper on Youth in Action 2.0. Available at http://youthpartnership-eu.coe.int/youthpartnership/documents/EKCYP/Youth_Policy/docs/YP_strategies/Policy/YIA20_FINAL.pdf (accessed 30 March 2013)

EYF (2010b) Policy Paper On Young People and Poverty. Available at http://youthpartnership-eu.coe.int/youthpartnership/documents/EKCYP/Youth_Policy/docs/Cohesion/Policy/Young_Pe ople_Poverty_FINAL.pdf (accessed 30 March 2013) 
Fawkes, J. (2004) Public relations and communications, in: A. Theaker (Ed), The Public Relations Handbook, pp. 18-31 (London: Routledge).

Fraser, N. (1992) Rethinking the public sphere: a contribution to the critique of actually existing democracy, in: C. Calhoun (Ed), Habermas and the Public Sphere, pp. 109-142 (Cambridge, MA: MIT Press).

Fraser, N. (1995) Politics culture and the public sphere: toward a postmodern conception, in: L. Nicholson \& S. Seidman (Eds), Social Postmodernism Beyond Identity Politics, pp. 287-312 (Cambridge: Cambridge University Press).

Greenwood, J. (2007) Interest Representation in the European Union (Basingstoke: Palgrave Macmillan).

Grimm, D. (1995) Does Europe need a constitution?, European Law Journal 1 (3), pp. 282-302.

Grunig, A. \& Grunig, J. E. (1992) Models of public relations and communication, in: J.E. Grunig et al. (Eds) Excellence in Public Relations and Communication Management, pp. 285-326 (Hillsdale, NJ: Lawrence Erlbaum Associates).

Guerrina, R. (2002) Europe: History, Ideas and Ideologies (London: Arnold).

Habermas, J. (1989) The Structural Transformation of the Public Sphere: An Inquiry into a Category of Bourgeois Society (Cambridge: Polity Press).

Habermas, J. (1995) Comment on the paper by Dieter Grimm "Does Europe need a constitution?", European Law Journal, 1(3), pp. 303-307.

Hajer, M. (2002) Discourse analysis and the study of policy making, European Political Science 2(1), pp. 61-65.

Hajer, M.A. \& Wagenaar, H. (Eds) (2003) Deliberative Policy Analysis: Understanding Governance in the Network Society (Cambridge: Cambridge University Press).

Harrison, J. \& Wessels, B (Eds) (2009) Mediating Europe. Mass Media, Mass Communication and the European Public Sphere (Oxford: Berghahn).

Howart, D. \& Torfing, J. (2005) Discourse Theory in European Politics (Basingstoke: Palgrave Macmillan).

Ingram H. \& Schneider A.L. (2008) Policy analysis for democracy, in: M. Moran, M. Rein \& R.E. Goodin (Eds) The Oxford Handbook of Public Policy, pp. 169-189 (Oxford: Oxford University Press).

Kingdon, J.W. (2011) Agendas, Alternatives and Public Policies (Crawfordsville: Longman).

Kohler-Koch, B. \& Rittberger, B. (Eds) (2007) Debating the Democratic Legitimacy of the European Union (Lanham: Rowman \& Littlefield).

Koopmans, R. \& Pfetsch B. (2003) Towards a Europeanised public sphere? Comparing political actors and the media in Germany, ARENA Working Paper 23. Available

http://www.sv.uio.no/arena/english/research/publications/arenapublications/workingpapers/working-papers2003/wp03 23.pdf (Last accessed 23 October 2013)

Laclau, E. \& Mouffe, C. (1985) Hegemony and Socialist Strategy: Towards a Radical Democratic Politics (London: Verso).

Liebert, U. (2007) Introduction: Structuring political conflict about Europe: National media in transnational discourse analysis, Perspectives on European Politics and Society, 8(3), pp. 235-60.

Mancini, P. (2003) Manuale di comunicazione pubblica (Roma and Bari: Laterza). 
Ruzza, C. (2004) Europe and Civil Society: Movements Coalitions and European Governance (Manchester: Manchester University Press).

Ruzza, C. \& Bozzini, E. (2008) Organised Civil Society and European Governance: Routes of Contestation, European Political Science, 7(3), pp. 296-303

Sánchez-Salgado, R. (2007) Giving a European dimension to civil society organizations, Journal of Civil Society, 3(3), pp. 253-269.

Sassatelli, M. (2009). Becoming Europeans: Cultural Identity and Cultural Policies (Basingstoke: Palgrave Macmillan).

Scharpf, F. (1998) Demokratie in der transnationalen Politik, in: U. Beck. (Ed) Politik in der Globaliserung, pp. 228- 253 (Frankfurt a. M.: Suhrkamp).

Schlesinger, P. (1999) Changing spaces of political communication: The case of the European Union, Political Communication, 16(3), pp. 263-79.

Schlesinger, P. (2003) The Babel of Europe. An Essay on Networks and Communicative Spaces, ARENA Working Paper (22). Available at: http://www.sv.uio.no/arena/english/research/publications/arenapublications/workingpapers/working-papers2003/wp03_22.pdf (last accessed 23 October 2013).

Schlesinger, P. \& Kevin, D. (2000) Can the European Union become a sphere of publics?, in: E.O. Eriksen and J.E. Fossum (Eds) Democracy in the European Union: Integration Through Deliberation?, pp. 206-229 (London: Routledge).

Schulz-Forberg, H. (2010) Cosmopolitanism or ethnic homogeneity? Roma identity, European integration and the European public sphere, in: C. Bee \& E. Bozzini (Eds) Mapping the European Public Sphere: Institutions, Media and Civil Society, pp. 177-194 (Aldershot: Ashgate Publishing).

Shore, C. (2000) Building Europe: The Cultural Politics of European Integration (London: Routledge).

Smismans, S. (Ed) (2006) Civil Society and Legitimate European Governance (Cheltenham: Edward Elgar).

Social Platform (2008) Annual Conference 2008 Report for Workshop 4: New faces in Europe: how can we connect with the 'hard to reach' communities across the EU? Available

at http://cms.horus.be/files/99907/MediaArchive/Events/Annual_conferences/SPA C_Workshop4_hard.pdf (accessed 30 March 2013]

Social Platform (2010) How to establish an effective dialogue between the EU and civil society organisations. Available at http://cms.horus.be/files/99907/MediaArchive/Policies/Participatory_democrac y/SocialPlatform EffectiveCivilDialogue.pdf (accessed 30 March 2013).

Statham, P. (2007) Political communication, European integration and the transformation of national public spheres: a comparison of Britain and France, in: J.E. Fossum \& P. Schlesinger (Eds) The European Union and the Public Sphere: A Communicative Space in the Making?, pp. 110-134 (London: Routledge).

Trenz, H.J. \& Eder, K. (2004) The democratising role of a European public sphere. Towards a model of democratic functionalism, Journal of European Social Theory, 7 (1), pp. 5-25.

Trenz, H.J. (2010) The Europeanisation of political communication: Conceptual clarifications and empirical measurement, in: C. Bee \& E. Bozzini (Eds) Mapping the European Public Sphere: Institutions, Media and Civil Society, pp. 15-30 (Aldershot: Ashgate Publishing). 
Van de Steeg, M. (2002) Rethinking the conditions for a public sphere in the European Union, European Journal of Social Theory, 5(4), pp. 499-519.

Verloo, M. (2005) Mainstreaming gender equality in Europe. A critical frame analysis approach, The Greek Review of Social Research, 117 (B): 11-34

Warleigh, A. (2001) Europeanizing civil society: NGOs as agents of political socialization in the European Union, Journal of Common Market Studies, 39(4), pp. 619-639.

\section{Notes}

${ }^{1}$ Margot Wallström was the Vice President of the European Commission for Institutional Relations and Communication Strategy under the first Barroso presidency 2004-2010.

${ }^{2}$ The documents were selected through the use of a series of key words to search in each organization's database. The initial sample included 45 documents ( 15 per category of citizen). On the basis of their relevance for our research question, we then selected 18 documents (6 per category). The analysis was executed with the support of a protocol for the analysis of policy documents divided into seven core sub-categories: policy actors, policy context, policy priorities, policy debates, EU policies, European crisis and counter_discourse.

${ }^{3}$ Civil dialogue is not to be confused with social dialogue. In its 2006 report Civil Dialogue: Making $i$ Work Better, the Civil Society Contact Group draws the difference between the two and argues that civil dialogue is 'developed as a parallel to that of social dialogue, it refers to a wide range of interactions between civil society organisations and institutions rather than a clear-cut set of practices' (CSCG, 2006, p. 22).

Formatted: Justified

Formatted: Italian (Italy) 